\title{
Betablokker eller betablokkerer?
}

\author{
Hvorfor heter det egentlig betablokker - og ikke betablokkerer? Disse legemidlene blokkerer jo betaresep- \\ torer, de blokker dem ikke.
}

Per Egil Hegge skrev nylig i sin språkspalte i Aftenposten at han fra en «god kilde» hadde fått vite at Tidsskriftet stadig bruker uttrykket betablokkere (1). I et tilsvar måtte jeg gi kilden rett (2). I Tidsskriftets ordliste, som ligger åpent tilgjengelig på nett, står flertallsformen betablokkere (3) - ikke betablokkerere, som Hegge foreslår. Det er ikke så rart. Her er vi på linje med samtlige norske ordbøker (4).

\section{Historikk}

Da betablokkerende medikamenter kom på markedet i 1960-årene, ble de omtalt i Tidsskriftet på ulike måter. Et søk i PubMed på «beta blockers AND Tidsskr Nor Laegeforen» gir første treff i 1968 (5). I artikler på denne tiden brukes flere former: «betablokade», «beta-blokerende middel» (5), « $\beta$-receptor blokker» (6), «betareceptorblokerende midler» (7) osv. Det første treff på «betablokker» som jeg har funnet, er fra 1970 (8). Siden ble det den foretrukne formen.

I Tidsskriftets spåkspalte i 1991 kritiserte indremedisineren Axel B. Aubert (19102006) denne språklige «slapphet», som han påtalte «så ofte som mulig» (9). Man blokker en urethra, men man blokkerer en reseptor. «Det lyktes meg virkelig en gang å få et medisinsk firma til å bruke den korrekte betegnelsen på norsk,» skrev han (9). Men han så nok selv at det ikke nyttet: Det er jo «den alvorlige hake ved dette forslaget at det blir en stavelse mer. Og da har vi vel ikke tid?».

Farmakologer og indremedisinere i Norge og Danmark sa først «beta-blockers», slik som i England, og skandinaviserte etter hvert ordet til betablokkere (10). Svenskene har imidlertid hele tiden sagt og skrevet betablockerare. I dag er begrepet betablokker så innarbeidet på norsk at det vil være nytteløst å prøve å fjerne det - slik det ble konkludert i Tidsskriftets språkspalte to år etter Auberts innlegg (10).

\section{Mer om blokkere}

I de senere år er det kommet en rekke medikamenter som blokkerer ulike reseptorer. Ett eksempel er H2-blokkere, som reduserer magesekkens syreproduksjon ved å blokkere H2-reseptorer. I stedet for å kalle

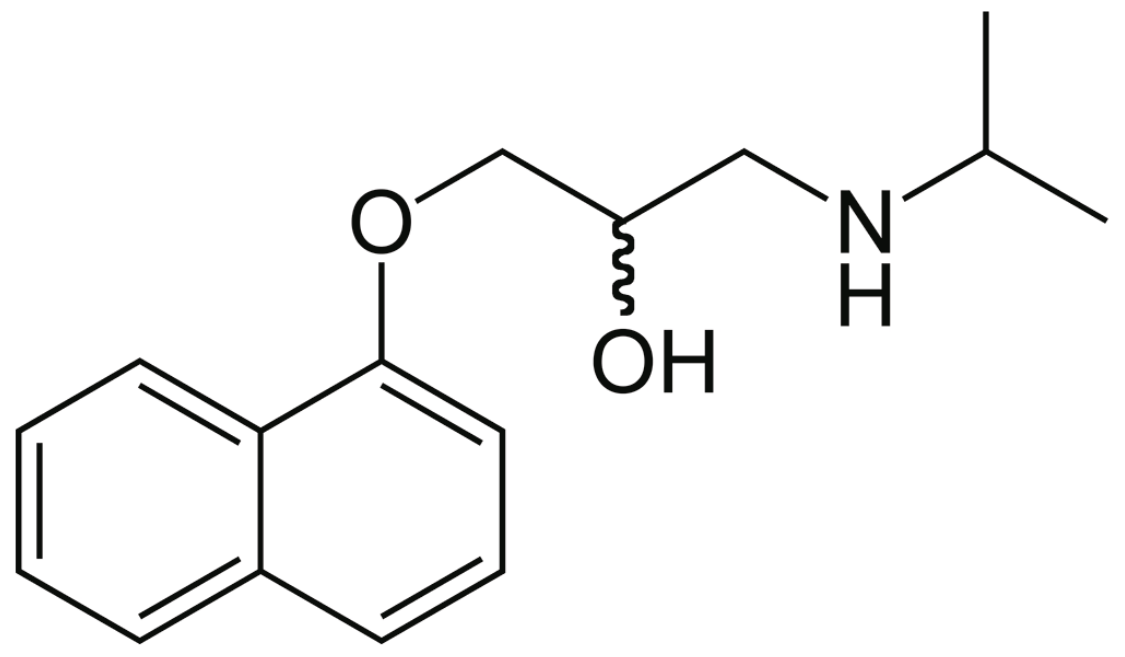

Propranolol var den første betablokkeren som ble brukt i stor utstrekning. Det ble syntetisert av den skotske legen sir James W. Black (1924-2010). Foto Wikimedia Commons

medikamentene H2-blokkerere, har man kalt dem H2-blokkere, analogt med betablokkere.

Hvis man vil unngå denne språklige inkonsekvensen, kan man omtale disse midlene som antagonister (11) - men man vinner vel knapt noe ved det.

Og hvorfor er det nok med én k i substantivet (blokade), mens det trengs to i verbet (blokkere)? Rettskrivningsreformen i 1959 innførte obligatorisk dobbeltkonsonant i verb på -ere når grunnordet hadde det, dvs. blokkere, fabrikkere, plassere og trafikkere mot før blokere, fabrikere osv. (12).

\section{Konklusjon}

Hvis man er i tvil om hvordan et ord skal skrives, bør man oppsøke en moderne ordbok. Der vil man finne at betablokker og ikke betablokkerer - har slått rot i språket. Grunnene til det er historikken, det engelske opphavet (blockers) og den enklere uttalen. Det kan vi leve godt med.

\section{Erlend Hem}

erlend.hem@medisin.uio.no

Erlend Hem (f. 1970) er dr.med. og konstituert sjefredaktør i Tidsskriftet.
Litteratur

1. Hegge PE. Blokking og blokkering. Aftenposten 14.1.2013: 4. http://tux.aftenposten.no/spraak/ spraak? action=question \&id=4886 (27.2.2013).

2. Hem E. Legemidler som blokkerer. Aftenposten 24.1.2013: 6 .

3. Ordliste B. Forfatterveiledningen. Tidsskrift for Den norske legeforening. http://tidsskriftet.no/ Innhold/Forfatterveiledningen/Spraak/Ordliste/B (27.2.2013)

4. Bokmålsordboka og Nynorskordboka. www.nob-ordbok.uio.no/perl/ordbok.cgi?OPP= betablokk \%25\&ordbok=begge (27.2.2013).

5. Hillestad L. Beta-blokade ved arytmier. Tidsskr Nor Lægeforen 1968; 88: 631-3.

6. Lund-Larsen PG. Aptin. En adrenerg $\beta$-receptor blokker. Tidsskr Nor Lægeforen 1970; 90: 110-1.

7. Aubert AB, Nyberg G, Slaastad R et al. Betablokerende middel ved angina pectoris. Et dobbelt blindfors $ø$ k. Tidsskr Nor Lægeforen 1970; 90: 409-13.

8. Erikssen J. Beta-adrenerg blokade som behandling ved thyreotoxikose. Tidsskr Nor Lægeforen 1970: 90: 1206-10.

9. Aubert AB. Kardiologisk språkslurv. Tidsskr Nor Lægeforen 1991; 111: 2676.

10. Stavem P, Lunde PK, Bjørkum A. Hjerteblokk, betablokker. Tidsskr Nor Lægeforen 1993; 113: 1909

11. antagonist - legemiddel som blokkerer. I: Store norske leksikon. http://snl.no/antagonist/ legemiddel_som_blokkerer (27.2.2013).

12. Wangensteen B. Utviklingen av bokmålet fra 1938 til i dag. Språknytt 1997; nr. 1. www.sprakrad.no/ Toppmeny/Publikasjoner/Spraaknytt/Arkivet/ Spraaknytt_1997/Spraaknytt_1997_1/Utviklingen_ av_bokmaalet_fra_/ (27.2.2013).

Mottatt 27.2. 2013 og godkjent 1.3. 2013. Medisinsk redaktør Raida Ødegaard. 